\title{
Cupola Furnace Design and Fabrication for Industrial Development
}

\author{
Yusuf Y. Ochejah'1, Ocheri Cyril2*, Ikani F. Omaone ${ }^{3}$, Adejoh F. Ogwudubi ${ }^{4}$ and Oyibo A. Onakemu ${ }^{5}$
}

1Engineering Works \& Services Department, Foundry Shop, Ajaokuta Steel Company Limited, Ajaokuta, Nigeria. 2Dept. of Metallurgical and Materials Engineering, University of Nigeria, Nsukka, Enugu State, Nigeria.

${ }^{3}$ Dept of Foundry Engineering, Federal Polytechnic, Idah, Nigeria.

${ }^{4}$ Engineering Works \& Services Department, Pattern Shop, Ajaokuta Steel Company Limited, Ajaokuta, Nigeria

${ }^{5}$ Dept. of Welding and Fabrication Engineering, Delta State Polytechnic, Ogwashi-Uku, Delta State, Nigeria.

*corresponding author details: Ocheri Cyril; cyril.ocheri@unn.edu.ng

\begin{abstract}
The Cupola Furnace Capacity of 450 kilograms per hour was designed and fabricated using locally sourced raw materials which include pig irons, crop ends and foundry shop returns, and ferroalloys for the production of quality cast iron which depends on the customer's demand. Metallurgical coke is the main fuel source employed for the production processes. The design parameters were analyzed and the metallic shells were then fabricated into four sections to allow proper lining. A mild $5 \mathrm{~mm}$ thick steel sheet was collected, marked out according to the required specification. slit and formed into cylindrical shapes. The sections were coupled and joined together through a welding process. Sodium silicate was used as a binder to make them bondable to the interior sections, the internal configurations were first lined with asbestos sheets measured $5 \mathrm{~mm}$ thick. with a less dense insulating refractory material. Fireclay refractory bricks were used for furnishing as they directly interfaced with the molten metal, while the flame blower was connected, assembled, and erected in the different segments. Financial analysis was performed to give a general overview of the cost of manufacturing and building a cupola furnace produced locally at N1,467,266.00, which is relatively cheap compared to the imported ones. The technical details were given for the production processes. The raw materials used were sourced locally as they are readily available in quantum and are essential to the government policies on adding values to the production processes by using these materials to promote the addition of these materials for the creation of local content.
\end{abstract}

Keywords: cupola; design; fabrication; local content; cast iron; financial analysis

\section{INTRODUCTION}

The Cupola furnace is one of the melting devices used mainly for the manufacture of different grades of bronze and cast iron in foundry processes. The melting processes in the furnace continue which is capable of processing pig iron, crop ends, foundry returns, and addition of ferroalloys to make the chemical compositions in a case where there is shortfall in the melting processes [1]. Metallurgical coke is the principal energy source for the operational procedures is one of the oldest cast-iron production methods, because of the simple operational processes it consumes a low amount of fuel and optimal technique [2]. The diameter of the cupola is expressed in terms of its height can be between $0,5 \mathrm{~m}$ and $4 \mathrm{~m}$ [3]. The furnace is cylindrical and sections are arranged in a vertical position to withstand the three or four stands [3].

At the base of the cylinder, there is a drop opening that swings down and out. The top where gases escape can be opened or fitted with a cover to prevent rain from entering the cupola. A cap designed to pull gases into a gas cooling system and eliminate particulate matter to control pollution [4] can be equipped with a cupola. The cupola shell has a refractory brick and plastic refractory patching material covering it, typically constructed from steel materials. materials. The bottom is similarly lined, but a clay and sand mixture ('Bod') can also be used, as this lining is temporary. Finely divided coal (seacoal) can be blended with the clay lining so that when heated, the coal decomposes and the bod becomes slightly friable, easing the opening of the tap hole. Squeezed against or rammed against the bottom doors is the bottom liner. Some of the cupolas have cooling jackets to keep the sides cold and oxygen-injected to make coke fire hotter [5]. The cupola is a counterflow vertical shaft furnace and, compared to batch type melters, has a high likelihood of good melting performance [6].

The research work was performed to encourage the fabrication and construction of this type or similar furnaces to rescue the moribund industries in Nigeria through the production of fast wearing spare parts. The processes will translate to the production of materials and solving the current rising unemployment rate which has become more pronounced in the country leading to kidnapping, armed robbery, banditry, and other social vices in the country that have caused havoc and chaos in all the social being. The furnace was constructed through the usage of raw materials gotten locally which could improve the nation's economic status, improve technological derives, and develop into skill 
acquisition and manpower development for the transformation of the country. The proceeds and products from the operations of the furnace will contribute to the sustainability of the industries for the production of spare parts and other components for the industrial operations cumulating to the products and skills. The research engineers will continue to advance their researches to improve the quality of the products and create new materials [7].

\section{EXPERIMENTAL PROCEDURES}

The main experimental procedure of the operational processes in the cupola furnace is based on the foundry processes which involve the melting and casting of various types of cast irons depending on the demand and need of the customers. Some peculiar characteristics of the cupola furnace have been used for the production of cast irons cumulating to having melting and casting units [8].

I. The furnace is used producing liquid metal in a few continuously working technique

II. Fast rates of melting

III. Relatively low costs for operations

IV. Simplicity of service

The cupola furnace is made of steel materials arranged in a vertical solid shelly position, which is lined with refractory brick, consists of the construction of a traditional cupola. Utilizing an opening device halfway up the vertically designed shaft [9]. The charge is placed into the body of the furnace. The load consists of various layers, coke fuel, and limestone, of the metal to be melted. In the air, the fuel is burned, which is added through tuyeres placed above the core. In the lower part of the shaft, the hot gases produced ascend and preheat the descending charge [10].

The cupola is the sort of Cut the foundation with hinged doors under the middle to help clean and rebuild. The metal fuel is approximately 450 kilograms an hour, resulting in melting. The period of cupola operations involves shutting and supporting the doors on the bottom and preparing the bottom of the hot spot. bottom at the end of the melting process [11]. There is a tap hole at the bottom of the front for the molten iron at the rear, a slag hole located above the tap hole. A spark/fume arrester hood is capped at the top of the stack. The internal diameter of the cupola is $380 \mathrm{~mm}$ and can function on different ratios of Normally, Low-strength sand moulding is made from the bottom and slopes into the tapping hole' [12].

Lightsticks are used, a fire is ignited in the hearth; the top of the furnace is charged with coke. By rising the air drawn from the tuyères maintains and burns the fire. If the required height of the coke bed is ignited, substitute metal, flux, coke layers are applied, and if the sum reaches the charging gate. The metal being paid for is pig iron, scrap steel, and foundry returns [13]. The chemical composition of all the charging materials is calculated by the use of electroanalytical methods known as SPECTRO LAB. An air blast is added by the wind box and tuyeres on the bottom of a cupola. The air reacts with the carbonaceous fuel chemically and thus produces heat from combustion. Shortly after turning on the blast, the molten metal is placed on the rim of the stove, where the ladle or the receptor finally is taped out [14].

As the metal is melted and fuel consumed, to provide a continuous supply of molten iron, extra loads are added to keep the charge door level. Charging is halted after the melting campaign, However, once the metal is all melted and tapped off, the air blast continues. The air is switched off and the doors below are opened so that the waste charger can be dumped [15].

\section{MATERIALS AND METHODS}

\section{Materials}

The material used for construction and manufacture of the cupola oven is mild steel sheets, steel angles, steel pipes, M24 bolts and nuts, asbestos sheets, less dense and isolationfriendly refractory bricks, dense, centrifugal electric blower, refractory cement, magnesite powder, zirconium sands and water glass (sodium silicate, $\mathrm{Na}_{2} \mathrm{SiO}_{3}$ ).

\section{Design, development, and selection of materials for} Cupola Furnace

The vertical steel shell, which consists of the principal components in the cupola furnace is the well/hearth, the combustion/melting region, preheating area and load area, pipes, the electric centrifugal blower, and the bottom cover. The cupola furnace design was based on the considerations and functionality of the different components/parts, the cost of the design, the local availability of materials/components, the availability of fuel, the ease of the manufacturing process, and the inner wall lining. The Cupola furnace is shown in FIGURE 1

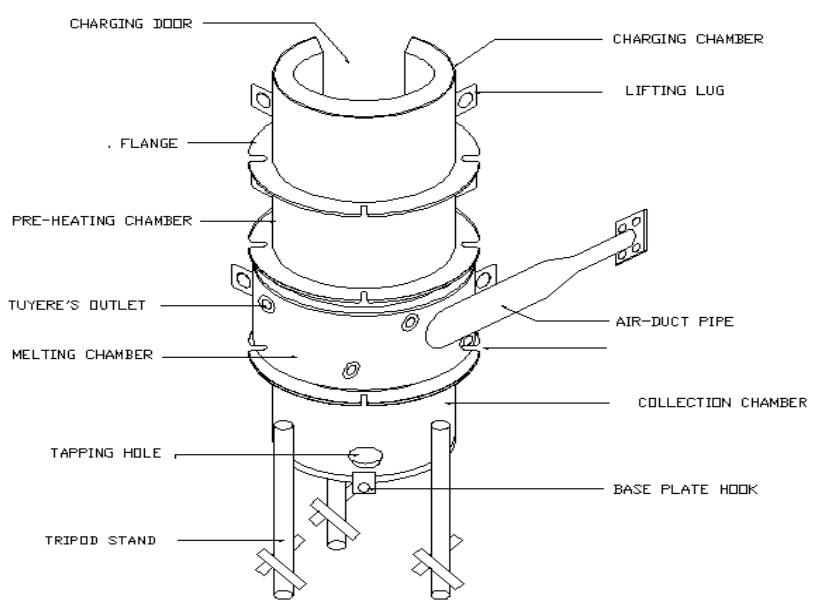

FIGURE 1: The assembled cupola furnace

\section{The Vertical Steel Shell}

The vertical steel shell is an arrangement of different areas forming the cupola furnace in which the charging material is melted to create cast iron. For construction, a mild steel plate was chosen as a material with good strength and the ability to withstand heat radiation for external structure, In the selection process, the outstanding also taken into account is the formability and solderability of mild steel. The design was completed, keeping in mind that the shell is well fortified and protected, to control heat loss and secure the outer shell with insulating materials such as asbestos, less dense refractory insulating bricks, and dense refractory bricks (fireclay) interfaced with the molded metal furnace [16].

The windbox is used to successfully deliver to the melting region which is blown by air to support combustion. The air-tight combustion zone linked to the electric centrifugal blower was made. The pipes air is blasted into the cupola furnace from which the operator is equipped with spy holes for tracking the melting procedure in the combustion zone. To allow the bottom sand to ram when closed, At the bottom of the furnace, a hinged door is fixed, preserving the liquid metal. To collect the molten cast iron and use it to finish the melt and release the cinders [17]. In the combustion area, hardwood firewood cut to sizes is conveniently positioned diagonally in the furnace center between the upper and lower rows of the pipes. To ignite the metallurgical coke, the firewood burns, forming a coke bed solid enough for load to be transported and melted to 
a molten state. Charging materials are pig iron, scraps of steel, returned foundry, flux, and metallurgical coke are continuously loaded as fuel until the door has hit the loading door. With a tapping spout and a slag spout from the well/hearth was constructed on its side by tapping the liquid metals and slag. The tapping sprout was pierced through before tapping, which was plugged with clay bodies [18].

Cupola Height Design Consideration and Measurements Concerning the diameter, the cupola furnace height is generally indicated. This varies between $4 \mathrm{D}$ and $6 \mathrm{D}$ and $5 \mathrm{D}$ is recommended for small cupola furnaces. $\mathrm{H}$, the effective couple height, is the width between the axis of the lower row of tubes and the recharging door [18]. Accordingly, as shown in equation 3.1, the effective height, $\mathrm{H}$ of the $5 \mathrm{D}$ furnace is recommended.

$\mathrm{H}=5 \mathrm{D}$

Where $\mathrm{H}=$ Height efficiency

$\mathrm{D}=$ Diameter of the cupola.

Accessible D = 284 (after lining its interior)

Equation 3.1,

$\mathrm{H}=5 \times 284 \mathrm{~mm}(1,420 \mathrm{~mm}$.)

\section{The Tuyeres}

Tuyeres have the purpose of conducting equal amounts of air in the cupola furnace from the wind surface to create a uniform combustion condition through the coke bed. The piping will be large and not have a very dramatic throttling impact on the blower to avoid any substantial pressure losses. A suitable area excess is given to allow one or more of the tuyere to be reduced by selecting the tuyere area for correcting a poor blast distribution within the specified range.

\section{Tuyeres architecture consideration and calculation}

The area and the number of pipes required were designed in two phases. The inner diameter of the cupola furnace at the point of the tuyere is the foundation of the tuyere. For small cupolas, typical ratios vary from $1 / 6$ to $1 / 4$ of the cupola cross-section area. You can measure the Tuyere region as follows:

The tuyere-level cross-sectional region [18] uses the $1 / 6$ scale. Two phases were used to design the area and the number of pipes required. At the point of the tuyere, the inner diameter of the cupola hob is the base of the tuyere. Typical ratios differ between $1 / 6$ to $1 / 4$ of the cross-sectional range for small cupolas.

The Tuyere area can be calculated accordingly:

The cross-sectional area [18] of the tuyere stage uses a scale of $1 / 6$.

The Area of the Tuyere $=A_{t}=1 / 6 A_{c}$

Where;

$\mathrm{A}_{\mathrm{c}}=$ Cross Sectional area of Cupola $\left(\mathrm{m}^{2}\right)$ or Area of well

$\mathrm{A}_{\mathrm{t}}=$ Cross-sectional area of Tuyeres

Also, $A_{c}=\pi\left(\frac{D}{2}\right)^{2}$

\section{Tuyere Number}

In each row, there are four tuyers with a diameter from $350 \mathrm{~mm}$ to $750 \mathrm{~mm}$ [9]. The tuyere number is four for the $600 \mathrm{~mm}$ cupola. The cross-sectional area of the four pipes together is $0.008 \mathrm{~m}^{2}\left(8000 \mathrm{~mm}^{2}\right)$.

Each of the four pipes has a transverse region of 81704 $=2042.5 \mathrm{~mm}^{2}$ or $0.0020425 \mathrm{~m}^{2}$

Tuyere Pipe Thickness:

$\mathrm{A}_{\mathrm{t}}=$ cross-sectional area of Tuyeres

consideration of each tuyere's cross-sectional area,

$A_{\mathrm{t}}=2042.5 \mathrm{~mm}^{2}$
But $A_{t}=\pi\left(\frac{D}{2}\right)^{2}$

Also; $\pi\left(\frac{D}{2}\right)^{2}=2042.5 \mathrm{~mm}^{2}$

Hence, $\mathrm{Dt}=\sqrt{\frac{(2042.5 \times 4)}{3.142}}$

$=50.993 \mathrm{~mm} \cong 51 \mathrm{~mm}$

Therefore, Tuyere diameter $=51 \mathrm{~mm}$ (steel pipe of diameter $51 \mathrm{~mm}$ ).

\section{Effective/Useful height of cupola well}

The cupola furnace's effective height between the tuyeres and the sand bottom is the portion of the cupola. It acts to trap the in the upper part of the furnace molten metal and slag melted and helps to separate them. The consideration of the height concerning the distance between the slagging hole and the sand bottom must be located at an opposite position to the tapping sprout which is the inmost case considered at the extreme position of the furnace as regards the determination of the well and hearth.

\section{Material Charging Mass}

The charge material mass is supplied [18] as;

$\mathrm{M}_{c m}=\rho r \times \mathrm{V}_{\mathrm{E}}$

Where: $\rho r=$ density of Iron $=7.6 \mathrm{~g} / \mathrm{cm}^{3}=7600 \mathrm{~kg} / \mathrm{m}^{3}$

$\mathrm{V}_{\mathrm{E}}=$ effective volume of surface $=\pi\left(\frac{D}{2}\right)^{2} \mathrm{H}=0.05924 \mathrm{~m}^{3}$.

$M_{c m}=7600 \times 0.05924=450 \mathrm{Kg}$

About $350 \mathrm{~kg} / \mathrm{hr}$ melt rate is the capacity of the cupola furnace.

\section{Parameter for Cupola Blower Selection}

The recommended blower size (Z) [18] is modified as follows:

$\mathrm{Z}=113 \mathrm{~A}_{\mathrm{c}} \mathrm{m}^{3} / \mathrm{min}$

$Z=113 \times 0.050=5.65 \mathrm{~m}^{3} / \min$. Where $A_{c}=0.050 \mathrm{~m}^{2}$

Blowers are always up to $12 \%$ to compensate for system leaks and temperature fluctuations. TABLE 1 accounts for the recommended Cupola blower sizes depending on the diameter of the oven and TABLE 2 also provides blower specification.

TABLE 1: Cupola blower sizes for operational procedure

\begin{tabular}{ccccc}
\hline $\begin{array}{c}\text { Inside } \\
\text { Diameter } \\
\text { in } \\
\text { (inches }^{2} \text { ) }\end{array}$ & $\begin{array}{c}\text { Area } \\
\text { (inches) }\end{array}$ & $\begin{array}{c}\text { Actual } \\
\text { cfm }\end{array}$ & $\begin{array}{c}\text { Recommended } \\
\text { Blower size } \\
\text { (cfm) m3/min. }\end{array}$ & $\begin{array}{c}\text { Discharge } \\
\text { pressure } \\
\text { Oz }\end{array}$ \\
\hline 10 & 78.5 & 216 & 6.12 & 8 \\
18 & 254 & 700 & 19.82 & 16 \\
23 & 415 & 1140 & 32.28 & 20
\end{tabular}

Source: [5]

\section{Refractory lining technique}

The technique deployed for the refractory lining is carried out due to the specific method chosen for optimal output of the furnace performance. The parameters considered include atmospheric gas, the production of slag either acidic or basic or neutral as been produced during the melting processes and the quality and kind of materials charged into the furnace, and the production cost considerations [19]. The selection of materials needed for the successful operational procedures becomes pertinent for the suitability of the lining materials. 
TABLE 2: Specification of the blower

\begin{tabular}{|c|c|c|}
\hline $\mathbf{S} / \mathbf{N}$ & Parameters & Quantity/Units \\
\hline 1 & $\begin{array}{l}\text { Required blade } \\
\text { number }\end{array}$ & 6 \\
\hline 2 & Rotated pace & $2890-3470 \mathrm{rpm}$ \\
\hline 3 & Volume flow rate & $1179-2062 \mathrm{~m}^{3} / \mathrm{hr}$ \\
\hline 4 & Rated stress & $220 \mathrm{~V}$ \\
\hline 5 & $\begin{array}{l}\text { Range of allowable } \\
\text { Pressure }\end{array}$ & 2840 - 2340 Кра \\
\hline 6 & $\begin{array}{l}\text { Pipe diameter of } \\
\text { the discharge }\end{array}$ & $95 \mathrm{~mm}$ \\
\hline 7 & Total dimension & $\begin{array}{l}690 \mathrm{~mm} \times 640 \mathrm{~mm} \times \\
910 \mathrm{~mm}\end{array}$ \\
\hline 8 & Power level & $5.5 \mathrm{~kW}$ \\
\hline
\end{tabular}

\section{Procedure of refractory lining}

The internal shell of the cupola furnace was first lined with the asbestos layer on the inside, less thick refractory isolation and refractory firebricks eventually followed closely. It was selected because of its ability to resist. The mechanical effect of the charged material, the chemical activity of liquid slag, and gaseous elements.
The joints between the pieces were kept as thin that could lead to bad lining conditions so that there was no slag attack on the joints. There was a minimum distance between the bricks and the paddle filled with gloves/sand to stretch the bricks and avoid hot spots on the shell if metal penetration was achieved in the brickwork joints.

\section{Lining of the furnace using refractory materials}

The heat loss and heat conservation in the cupola stove have now been minimized by refractory insulation. They have high porosity, low thermal conductivity, and high thermal insulation. The reconstruction of refractory isolation decreases the consumption of fuel, contributing to high efficiency due to high working temperatures and improved working conditions for shop floor workers.

\section{Cost Analysis}

TABLE 3 presents every part and equipment for the development of cupola furnaces. The materials and equipment used in the design are localized and the total cost of the cupola kiln design and development is around $\mathrm{N} 1,467,266.00(\$ 3,702,037$ at N396.34/\$). Cupola furnace costs $\mathrm{N} 9,357,983,74, \mathrm{~N} 9,357, \$ 23,621,00$ at N397,34/\$, and is cost-effective for transport and clearing [20]

TABLE 3: Proposal for the assessment of engineering materials

\begin{tabular}{|c|c|c|c|c|c|}
\hline S/No & Material Description & Items & Quantity & Unit Cost & $\begin{array}{l}\text { Total Cost } \\
\text { (N) }\end{array}$ \\
\hline 1 & Mild Steel sheet 5 mm X 1200 X 24000 & sheets & 4 & $20,000.00$ & $80,000.00$ \\
\hline 2 & Steel pipe (Ø64 X 400 mm X 8 nos) & meters & 3.2 & 800.00 & $2,560.00$ \\
\hline 3 & Blower pipe (Ø127 X 1 meter) & meter & 1 & $4,500.00$ & $4,500.00$ \\
\hline 4 & Welding Electrodes - gauge 10 & packets & 3 & $3,500.00$ & $10,500.00$ \\
\hline 5 & Welding Electrodes - gauge 12 & packet & 1 & $2,800.00$ & $2,800.00$ \\
\hline 6 & Grinding disc & nos & 3 & 800.00 & $2,400.00$ \\
\hline 7 & Cutting disc & nos & 6 & 800.00 & $4,800.00$ \\
\hline 8 & Base plate for the bottom door & $\emptyset 675 \mathrm{~mm}$ & 1 & $4,800.00$ & $4,800.00$ \\
\hline 9 & Angle bar: $5 \mathrm{~mm}$ X $65 \mathrm{~mm}$ X $65 \mathrm{~mm}$ & piece & 1 & $4,500.00$ & $4,500.00$ \\
\hline 10 & Firebricks lining (50 X 100 X 188) & piece & 288 & $1,500.00$ & $432,000.00$ \\
\hline 11 & Steel pipe (Ø75 mm X 1500 mm X 3 nos) & $\mathrm{mm}$ & 2 & $4,500.00$ & $9,000.00$ \\
\hline 12 & 7.5 Kw Blower (Three-phase) & no & 1 & $155,000.00$ & $155,000.00$ \\
\hline 13 & Fireclay cement & bags & 10 & $5,000.00$ & $50,000.00$ \\
\hline 14 & Design cost & & 1 & $150,000.00$ & $150,000.00$ \\
\hline 15 & Plotting of design drawings & & 1 & $20,000.00$ & $20,000.00$ \\
\hline 16 & Welding of the entire shell & & 1 & $30,000.00$ & $30,000.00$ \\
\hline 17 & $\begin{array}{l}\text { Transportation of cupola and accessories to } \\
\text { the site }\end{array}$ & & 1 & $60,000.00$ & $60,000.00$ \\
\hline 18 & Painting of the cupola furnace & & 1 & $15,000.00$ & $15,000.00$ \\
\hline 19 & Pig iron for test running & ton & 1 & $99,891.00$ & $99,891.00$ \\
\hline 20 & Steel scrap (crop ends) & ton & 0.4 & $80,000.00$ & $32,000.00$ \\
\hline 21 & Lime stone & ton & 0.2 & $20,000.00$ & $4,000.00$ \\
\hline 22 & Ferro-alloys ( Fe-Si, Fe-Mn, Fe-Cr) & ton & 0.1 & $385,150.00$ & $38,515.00$ \\
\hline 23 & Metallurgical coke & ton & 1 & $55,000.00$ & $55,000.00$ \\
\hline \multirow[t]{2}{*}{24} & $\begin{array}{l}\text { Erection, concentrating the platform and } \\
\text { electrical work }\end{array}$ & & 1 & $200,000.00$ & $200,000.00$ \\
\hline & TOTAL & & & & $1,467,266.00$ \\
\hline
\end{tabular}




\section{CONCLUSIONS}

A working cupola furnace with a molten cast iron capacity of 450 kilograms per hour designed and constructed for this study. The research work was based on the operationalization of a cupola furnace being operated at the foundry shop of the Ajaokuta Steel Company Limited, Ajaokuta; Kogi State. The significance in reproducing similar furnaces for the Department of Metallurgical and Materials Engineering, Federal University of Technology, Akure, Ondo State, Nigeria was borne out of the fact that the furnace can produce liquid metal continuously, effectively. efficient and turning out quality cast iron. These assertions were hinged on the principle that the dexterity and skillful acquisition of the operators of the furnace was second to none.

In line with the government policies on using local contents as part of the production standard in Nigeria, some locally sourced materials like the zircon sand were used on the interface of the furnace; this material is readily available in the northern part of the country and absolutely at a relatively lower cost. The material is known to increase the life of the furnace lining, which has the property of bondability as a neutral environment on the refractory lining by allowing it to work without a marked reaction in acidic and simple conditions. Cupola will also encourage the ease of costeffective production of cast iron melt and enable small-scale entrepreneurship to be used for efficient operating processes and revenue generation. The process also encourages retaining foreign exchange, which plays an important role due to its inherent characteristics in the metal recycling industry. The design and manufacture of the cupola furnace were carried out using locally sourced materials for the promotion of local content development in Nigeria. The project is a worthwhile development, as this process will reduce the cost of importation by one-tenth as compared to the imported ones where a similar quantity of cast iron production is required.

Owing to the lack of simple fast-wearing machine parts, the current unemployment rate is large because our indigenous companies are in a comatose state. Therefore, the design and manufacture of cupola furnaces using locally sourced materials and indigenous technology will improve the situation by enabling metallurgical industries and institutions to embark on the casting of simple and complex spare parts appropriate for the activity of our ailing industries. In improving the quality of goods and producing new materials, the use of the furnace will accumulate, as continuous operational processes will offer many opportunities for improving the dexterity of aspiring researchers and engineers to develop their research and gain more operational skills for optimal and efficient service delivery.

\section{REFERENCES}

[1] Edward, K. "Cupola Furnace - A Practical Treatise on the Construction and Management of Foundry Cupolas". Philadelphia, PA: Baird. (2008). Pp 95 - 250]

[2] Moore et al 1995 "A multivariable Smith predictor for intelligent control of a cupola furnace" Proceedings of 1995 American Control Conference - ACC'95 Published: IEEE DOI: 10.1109/ACC.1995.520956 Seattle, WA, USA, USA, 1995

[3] Larsen, E.D., Clark, D.E., Smartt, H.B., and Kevin L. M. Intelligent Control of Cupola Melting, Transactions of the American Foundrymen's Society, Vol. 95-96, (2005). pp. 215-219.

[4] Stewart, M Building small cupola furnaces, Marshall Machine and Engineering Works, Lopez Island Technologies Company. (1996), pp $214-220$
[5] Chastain D. S. Iron melting cupola furnaces for the small foundry. Jacksonville, FL; USA. 770223-3. (2000). pp.86.

[6] Kirk, E. "Cupola management". Cupola Furnace - A Practical Treatise on the Construction. (1999). Pp 6-12

[7] Steven, C). Iron Melting Cupola Furnaces for the Small Foundry, ISBN 0970220308 (2000), pp 100-149,

[8] Ugwu H.U. and Ogbonnaya, E.A. Design and testing of a cupola furnace for Michael Okpara University of Agriculture, Umudike. Nigerian Journal of Technology (NIJOTECH) Vol. 32, No.1, (2014), pp.22-29.

[9] Lipnitsky A. "Melting of cast iron and non-ferrous alloys". Peace Publisher, Moscow, (1978), pp.56

[10] Gupta, O. P. "Elements of fuels, furnaces, and Refractories", Khanna Publishers, India (2011). pp 200-205.

[11] Nwajagu, C. O., and C. E. Ilochonwu) "Understanding the Technology of Cupola Operation and Management Using Local Fabricated Cupola (2015, pp 1

[12] Ocheri C "Design, Fabrication and Construction of Cupola Furnace for Metallurgical Industries" Journal of Applied Material Science \& Engineering Research App Mat Sci \& Engg Res, 2020 Volume 4 | Issue 4 www.opastonline.com 2020 pp 134-141

[13] A. A. G Olorunnishola1 and S. A Anjorin 2 "Development of a Statistical Model for the Effects of Air Blast Pressure, Melting Time and Fuel Consumed on Iron Melting Rate of an Erythrophleum Suave lens Charcoal-Fired Cupola Furnace" Published under license by IOP Publishing Ltd Journal of Physics: Conference Series, Volume 1378, Issue 4 2019

[14] Copula Furnace https://en.m.wikipedia.org/wiki/Cupola_furnace

[15] Production Engineering Cupola Furnace: Principle, Construction, Working, Advantages, Disadvantages and Application January 6, 2018 HTTPS ://www.mech 4study .com /20 18 / 01 cupola-furnace.html

[16] Oladele Isiaka Oluwole and Okoro Moses Avwerosuoghene "Effects of Cassava Starch and Natural Rubber as Binders on the Flexural and Water Absorption Properties of Recycled Paper Pulp Based Composites" JETIInternational Journal of Engineering $\&$ Technology Innovations, Vol. 2 Issue 4, August 2015 ISSN (Online): 2348 -0866 www.IJETI.com

[17] Copula Furnace "industrial metal castings .com http://www. Industrial metal castings.com /foundries_cupola_furnace.html

[18] Olorunnishola, A. A.G, and ${ }^{* *}$ Anjorin, S. A." Design, Construction and Testing of An Erythrophleum Suaveolens Charcoal-Fired Cupola Furnace for Foundry Industries in Nigeria" European Journal of Engineering and Technology Vol. 4 No. 1, 2016 ISSN 2056-5860 pp 1-16

[19] Copula Furnace http://sns.chonbuk.ac.kr/manufacturing/casting-36.htm

[20] M Perzyk, A Kochański "Detection of causes of casting defects assisted by artificial neural networks" Proceedings of the Institution of Mechanical Engineers, Part B: Journal of Engineering Manufacture First Published September 1, 2003, Research Article https://doi.org/10.1243/095440503322420205 